\title{
The Good People: Loyalty and Betrayal in Moscow's House of Government, 1937-1938
}

\author{
Labie ḷaudis: lojalitāte un nodevība PSRS Valdības namā \\ 1937.-1938. gadā
}

\author{
Yuri Slezkine \\ Professor of the Graduate School at the University of California, Berkeley \\ 3229 Dwinelle Hall \\ University of California \\ Berkeley, CA 94720-2550 \\ Senior Research Fellow, St. Edmund Hall, University of Oxford \\ Visiting Professor \\ Faculty of History and Philosophy, University of Latvia \\ Aspazijas bulvāris 5, Rīga, LV-1950 \\ E-mail: Slezkine@berkeley.edu
}

This essay is an abridged and revised excerpt from the book The House of Government: A Saga of the Russian Revolution. It deals with the reactions to mass arrests of 1937-1938 within the House of Government in Moscow, including silence, vigilance, book-burning, soul-searching, and self-sacrifice. The central questions have to do with the puzzle of what constituted moral behavior, what was meant by loyalty and betrayal, and who, and why, could be considered a "good person."

Keywords: Soviet repressions, Russian revolution, morality in extreme situations, House of Government.

Šis raksts ir saīsināts un pārveidots izvilkums no autora monogrāfijas "Valdības nams: Krievijas revolūcijas sāga". Tajā aplūkota reakcija uz masu arestiem Valdības namā 1937.-1938. gadā - tā ietvēra klusēšanu, pretestību, grāmatu dedzināšanu, garīgu un morālu pašanalīzi un uzupurēšanos. Galvenie jautājumi ir saistīti ar vairākām problēmām: ko nozīmēja morāla rīcība, kas tika saprasts ar lojalitāti un nodevību un kurš un kāpēc varēja tikt uzskatīts par labu cilvēku.

Atslēgvārdi: padomju represijas, Krievijas revolūcija, morāle ārkārtas apstākḷos, valdības nams.

The most common reaction to the multiplying disappearances in the House of Government was silence. Even the show trials were rarely commented on. The people in the government part of 
the House did not seem to doubt the guilt of the accused or the authenticity of their confessions: they seemed to refrain from mentioning them as a matter of ritual avoidance of the unclean. Only children and very old Old Bolsheviks might ask a question, which no one would consider answering. Even in prison reception rooms, the relatives of the arrested tried, according to Irina Muklevich, "not to talk and not to recognize each other. Hundreds of people would stand in a relatively small room, but it would be quiet and tense. They were all thinking of their own grief, like at a funeral." 1

On the last day of the KamenevZinoviev trial (August 1936), the chairman of the All-Russian Society for Cultural Relations with Foreign Countries (VOKS), Aleksandr Arosev (Apts 103 and 104), was in the Sosny rest home on the Moskva, writing in his diary.

"In today's papers we read that Kamenev, Zinoviev, Panaev, Mrachkovsky, Evdokimov, Ter-Vaganian, I. N. Smirnov Reingold, Goltsman, M. Lurye, N. Lurye, Dreitser, Olberg, and Perman-Yurgin have all been sentenced - to be shot.

M. P. Tomsky ${ }^{2}$ shot himself the other day.

Today Aralov told me that Comrade Piatakov had tried to poison himself, but apparently failed and was taken to the hospital.

No one is saying anything. Everyone talks as if nothing has happened.

'Did you go for a swim today?'

'No, I took a shower.'

At the other end of the table:

'Do you play tennis?'

'Of course.'

Someone else:
'Have some half-sour pickles. They're delicious." $" 3$

All Arosev himself had to say was that Kamenev and Zinoviev were "demons". Five months later, on the last day of the Karl Radek trial, he listed the sentences, copied a long excerpt from Lion Feuchtwanger's Pravda article, and agreed with the author that "only the pen of a great Soviet writer could explain to the people of Western Europe the crime and punishment of the accused." Arosev's own plan was to write a novel in the form of interrogation transcripts. Only "by means of aesthetic impressions," he wrote, could one make sense of "the zigzags that have brought people from the revolution to its opposite." This was true because Arosev was a fiction writer who hoped to represent the age with "the greatest possible generalizability." It was also true because there was no other way to make sense of the zigzags. One of the accused at the trial was Nikolai Muralov, whom Arosev, at Rozengolts's request, had appointed Commissar of the Moscow Military District on November 2, 1917. ${ }^{5}$

Another common reaction was to cleanse one's life of all connections to the excommunicated. Some House residents mostly women - burnt books and letters, cut faces out of photographs, changed their children's last names, and avoided contaminated neighbors and relatives. As in most struggles with the onslaught of the unclean, this was both a practical precaution and the extension of ritual silence to new sources of contagion. Some people reduced their possessions to a few things they might need in prison and waited silently for the knock on the door. The former head of the central censorship office, Boris Volin (Apt. 276), had a suitcase with warm things stored behind his couch. His wife burned the entire family archive. In the fall of 1937, he had a heart attack and 
was sent to the Kremlin hospital and then to a sanatorium in Barvikha. When he came back three months later, most of his neighbors and colleagues (he was First Deputy of the People's Commissar of Enlightenment) had disappeared. The former head of the Bookselling Directorate, David Shvarts (Apt. 444), would stay up at night, looking out the window. According to his son, "the window looked out onto the courtyard. Whenever a "black raven" [NKVD car] would enter the courtyard, my father would start getting dressed." 6

Attempts at self-cleansing and readiness for self-sacrifice were accompanied by vigilance toward others. Two and a half months after Sergei Kirov's murder (December 1, 1934), when he was still chief censor, Boris Volin issued an order informing local censorship offices that the "expertly camouflaged work of the class enemy" had been detected "on the fine arts front."

"By means of different combinations of colors, light and shadow, strokes, and contours disguised according to the method of 'mysterious drawings', the enemies are smuggling in counterrevolutionary content. The symbolic painting by the artist, N. Mikhailov, "By Kirov's Coffin", in which a certain combination of light, shadow, and color represent the outline of a skeleton, has been qualified as a disguised counterrevolutionary act.

The same has been detected on the tin can labels printed by Supply Technology Publishers (a human head instead of a piece of meat surrounded by beans). [...]

In light of the above, I order that:

All censors working with posters, paintings, labels, photo montages, etc. undertake the most thorough scrutiny possible of such material, not limiting themselves to superficial political meaning and overall artistic value, but considering carefully the entire artwork from all angles (contours, ornament, shadows, etc.), frequently resorting to a magnifying glass."

At the height of the campaign against hidden enemies, a magnifying glass was to be directed at everyone, by everyone. On July 27, 1937 (the day Osip Piatnitsky from Apt. 400 was arrested), the writer Aleksandr Serafimovich (Apt. 82) received a letter from his old friend, Mirra Gotfrid, asking for the telephone number of the head of the Writers' Union, V. P. Stavsky. She needed to talk to him about the novella she was translating by the Yiddish writer, David Bergelson.

"In the process of work on the translation I uncovered the petit-bourgeois nature of the novella and three subsequent meetings were enough to uncover something quite serious about the author it worries me very much I must see Comrade Stavsky believe me I wouldn't be bothering you for no reason. My observations are serious and this writer must be checked out very carefully. Write to Stavsky and ask him to receive me. You know I wouldn't be making a fuss over nothing. All the best to you. Thank you for all the good things. Warmest regards to Fekola. Why don't you do it this way send me Comrade Stavsky's phone number and drop him a line asking him to listen to what I have to say and telling him that I am observant and don't accuse people without evidence and that I would consider it a criminal act to keep silent and not report to the Writers' Union president (who is also a member of the Control Commission now). Help me out. Mirra, 27 July, 1937."

Platon Kerzhentsev from Apt. 197 also felt the need to be vigilant. In early March, 1938, he was at home awaiting arrest after his dismissal from the Committee for 
the Arts and the suicide of his deputy, Naum Rabichev. On the second day of the Anti-Soviet Rightist-Trotskyite Trial (March 1938), which involved three Kremlin doctors accused of murdering Soviet officials, he sent a handwritten note to Molotov, with a copy to Prosecutor General Andrei Vyshinsky:

"In connection with the charges against D. Pletnev, I consider it necessary to remind you of the circumstances of the death of Comrade Dzerzhinsky.

After his heart attack he was put in the room next to the meeting room. Several hours later the doctors allowed him to go back to his own apartment. When he got home and bent over his bed, he fell down dead.

As is well known, after a heart attack the patient is absolutely forbidden to move in any way (especially walking, bending).

Among the doctors attending to Dzerzhinsky was Pletnev.

By allowing Dzerzhinsky to go, he killed him.

\section{$[\ldots]$}

As for Kazakov, I can share my personal experience: my second heart attack happened exactly four hours after the very first injection administered by Kazakov.

Yours, Kerzhentsev, 8 March, 1938"9

Three days later, after the accused had had a chance to tell their stories, the head of the All-Union Radio Committee, Feliks Kon (Apt. 198), wrote to his lover, Maria Komarova, that their next meeting would have to be postponed because of bad weather, but that he would do his best to make up for it when the time was right. "Will I be able to? Will I? But I'll try. Okay?" His late love made him "feel alive, feel young again." And so did the spectacle of the Anti-Soviet Rightist-Trotskyite Trial. $^{10}$

"I miss you in earnest. Each time after I read the newspapers, I come close to losing my mind. Have entire generations struggled and have people died at the gallows, in dungeons, at the barricades, and in the Civil War just so these vermin could betray it all? Bukharin trying to kill Lenin and Stalin, Rozengolts with a prayer-amulet in his pocket ready to murder Stalin... Yagoda, Levin... It's like a villainy contest among scoundrels. And what about the attempt to poison Ezhov? You read something like this and then spend the rest of the day as if someone had spat into your soul. But still, despite all their scheming and their fascist conspiracies, we continue to advance, and now that Ezhov is in charge, things will get even better. If not for my 74 years, I would have approached Ezhov and volunteered to become his assistant. I would not have wavered. I would have killed those monsters with my own hand. I have lived through many assaults, but I never suspected that such creatures existed. Brrrr!"11

For Efim Shchadenko (Apts. 10 and 505), the struggle against wreckers was a time of revenge for years of humiliation at the hands of "neurotic degenerates" and other clouds in pants from "the intelligentsia in general and the Jewish intelligentsia in particular". Most recently, he had lost a protracted feud with the former tsarist officers and his superiors, the commander of the Frunze Military Academy, August Kork (Apt. 389), and the Deputy Commissar of Defense, Marshal Tukhachevsky (Apt. 221), both former tsarist officers. On August 17, 1936, Kork wrote to Tukhachevsky: 
"The state of health of my deputy, Comrade Shchadenko, is extremely precarious. It is my impression that, at any moment, Comrade Shchadenko may succumb to a fit of raving madness. I request that Comrade Shchadenko be relieved of his duties at the academy and transferred to the care of doctors without delay."

Tukhachevsky endorsed the request and Shchadenko was dismissed (and spent three and a half months in a hospital). In May, 1937, Kork and Tukhachevsky were arrested and, within three weeks, both executed. Their close colleague, Deputy People's Commissar of Defense, Yan Gamarnik (Yakov Pudikovich), committed suicide. Shchadenko was sent to Kiev to "liquidate the consequences of wrecking". On July 10, he wrote to an old Civil War comrade: ${ }^{12}$

"We must destroy this treacherous scum without mercy, the way we did during the Civil War, no matter what colors they use to camouflage themselves and no matter how leftist their reptile hissing may sound.

Death without mercy to the fascist lackeys, spies of the German-Japanese imperialism - such is our response to the scheming and sabotage on the part of the enemies of the people.

I am, as usual, merciless toward the enemy, hacking at them right and left, annihilating them along with their villainous acts." 13

On November 20, he wrote to another former comrade, reminding him of his (Shchadenko's) “implacable struggle against the German spy Kork, the vile governor scum Tukhachevsky, Gamarnik and the whole sellout gang of the Trotskyite-Bukharinist bloc." But his main correspondent, confidante, and fellow socialist realist was his wife,
Maria Denisova. On June 18, he wrote from Kiev:

"My darling little sun, I miss you so much and worry so much when, exhausted, I finally tear myself away from my work and drag myself to my - quite literally - soldier's bunk. There is so much work that I cannot leave Headquarters until 2 or 3 in the morning. The wrecker scum spent years fouling things up, and we only have weeks, or a month or two at the most, to not only liquidate all the consequences of sabotage, but to start moving forward. The cowardly scoundrels, undetected by the cheerful carelessness of our "defenders", sneaked into high positions, corrupted the guards, filled the apparently watchful sentries with the poison of doubt, and hatched an unimaginably villainous plot.

It is our great fortune that, early on, Stalin himself noticed and felt the danger of the fascist terrorist murderers getting close to him and began to take measures, not giving in to pleas for mercy for Enukidze (that most vile and well-disguised of reptiles), cast him, along with the rest of his gang, out of the Kremlin, recruited new, reliable guards, and, having appointed Comrade Ezhov, that modest and diligent worker, began to untangle the knots and threads of fascist designs for the bloody restoration of capitalism. [...]

I have a great deal of work, but working is easy because now I feel that I have vast creative freedom to fight with and for the masses, and, most important, that the truly great Stalin can, once again, see the same ability and selflessness that I demonstrated when he saw what I did during the Civil War.

I embrace and kiss you very tenderly, my darling little sun. Soon, no later than early 
July, I'll be in Moscow and then I'll try to bring my dear family back here with me."14

In November, he returned to Moscow as Deputy People's Commissar of Defense in charge of commanding personnel. Meanwhile, Maria herself seems to have succumbed to fits of raving madness. According to Maya Agroskina (Dementieva), who lived in Apartment No. 17 , she once broke into someone's apartment wearing a nightshirt and wielding a gun. According to Ruslan Gelman, who lived in Apartment No. 13.

"She lived in a huge apartment that had been converted from two smaller ones, with a few servants. Occasionally, she'd appear on the landing. She made a strong impression. She was a tall, stout woman with a piercing, menacing glare. Think of Surikov's [sic] painting, "Tsarevna Sofia": that's her portrait, as if she had posed for it herself. Add to that a long black dress girded by a soldier's leather belt, a kitchen knife stuck into it, and her hand resting on the handle... It was truly a sight to behold! To amuse herself, she used to leave a chair out on the staircase with a vase full of fruit and a tightly packed lady's purse with high-denomination bills sticking out. Sometimes that chair would remain there for several days.

Once she came over to our place. The only ones home at the time were me and our maid, a very young girl, who was deathly afraid of her. When I opened the door after the bell rang, the maid ran into the bathroom and locked herself in. The fearsome Tsarina swept past me, this time without her knife, but with a retinue: a young man in semi-military uniform. His job must have been to look after her, but he did not dare contradict or restrain her. She spent a long time looking around our apartment and even measuring some things, talking complete gibberish all the while, and finally left, with a parting threat." 15

\section{$* * *$}

Maria Denisova was trying to do at home what her husband was doing at work. Both had their sanity questioned by the people they tried to expose, and both were being vindicated by the daily exposure of "monsters in human form".

After the arrest of her seventeen-yearold son, Igor, Yulia Piatnitskaia began to question her own sanity. "I cannot even admit to myself the kinds of thoughts I am having about him," she wrote in her diary on February 25, 1938. "For as long as I have a bit of reason and a lot of love, I'll continue to wait. But I foresee torments terrible for my heart in the coming days." 16

Her heart's most terrible torment concerned the soul of her husband, who had been in prison for seven months. "Who is he?" she asked in her diary. "If he is a professional revolutionary - the kind he described in his book, the kind I saw in him for seventeen years, then he was struck by a terrible misfortune." But what if he is not? What if he actually is a monster in human form?

"It is clear that Piatnitsky has never been a professional revolutionary: he has been a professional scoundrel, a spy or secret agent like Malinovsky. That is why he has always been so grim and withdrawn. In the darkness of his soul, there was nothing to do but wait until he was discovered or managed to escape punishment.

We, his wife and children, have never been of much importance to him. Now, the question is: who did he serve? And why? He must have started because tailoring was hard and 
uninteresting, so he got involved in revolutionary work and, somehow, because of his cowardly nature, became a secret agent. Somebody must have discovered something: how he became a traitor or when he became a traitor, then the revolution happened and he realized how good the real struggle for socialism was, but the spies obviously would not let him work and he spent all those years working for the counterrevolution and surrounding himself with people like him. Piatnitsky's life could have gone like this. But who is he: this one or that one? I don't know, and it hurts. When I think of this first one, I feel so sorry for him and want to die or to fight for him. When I think of that second one, I feel tainted and disgusted, and I want to live in order to see them all caught and have no pity for them. I could spit in his face and call him a 'spy'. Vova must feel the same way." 17

Their twelve-year-old son, Vova (Vladimir), wanted to be a sniper and a border guard. "What a bastard Dad is," he said once, "to go and ruin all my dreams like that." On February 25, 1938 he spent all day reading a book about the Red Army. When he finished, he said: "It's too bad Dad hasn't been shot, since he's an enemy of the people."18

\section{"Yulia was not sure it was true.}

In the depths of my soul, in my inmost self, I clearly have no feeling of distrust for that man. He cannot possibly be an enemy of the Party he valued above all else in life. He cannot possibly be an enemy of the proletariat, whose interests he served all his life, to the best of his ability. It is still too early to talk about this without emotion. But the time will come, and you will still be certain of this, and your heart will sing because you will know that his thoughts and his heart were pure before the Party."
But then, why had he been arrested? The Party did not make mistakes, and Piatnitsky's arrest had been authorized by the Party.

"I trust Piatnitsky, but I trust Ezhov's holy work even more. 'Even the Sun can have an eclipse,' but nothing can eclipse the Sun. The Party is the Sun of our lives, and nothing can be dearer than its health, and if sacrifices are required (and if your life has been cut down by accident), find the strength to remain a human being, in spite of everything. My darling little Igor, my sacred little boy, I know you will understand everything if you do not die. You are too young to go through something like this."19

The only way to reconcile both sides of her heart was to think of Piatnitsky's arrest as a necessary sacrifice. This meant that Igor's arrest must also be a necessary sacrifice. But it was not. It was a redemptive trial.

"As for my Igor, I think along with F. [Engels]: "Whatever is healthy can withstand a trial by fire. The unhealthy elements we will happily discard..." The day of the great decision, the day of the battle of nations is near, and the victory will be ours."

She knew that Igor belonged among the chosen and was needed at Armageddon. It was Piatnitsky she was not sure about. ${ }^{20}$

Some relief was provided by the trial of Bukharin, Rykov, and other enemies. They were the ones "who had sowed mistrust, hostility, slander, and cruelty." Their unmasking and destruction would make it "easier to breathe". On March 3, the day Koltsov's article about the pack of bloodhounds came out, Yulia stayed home all day.

"I have used up all my physical strength. During the day, while I was alone in 
the apartment (Grandma had brought me the newspaper), I suddenly woke up with a stomach cramp. Without quite realizing it, I had broken into a 'dance of joy' at the decisive routing of those 'beasts'. To think that I used to respect some of them, although Piatnitsky had warned me about B. and what a scumbag he was. He told me about how he had sat on the floor in their midst, unshaven and clad in some old suit, and that no one had said hello to him. They already viewed him as a stinking corpse. And now he has turned out to be even more frightening, more treacherous than anybody could have imagined. 'Death' is too easy a punishment for them, but the working people should not have to breathe the same air as them. Oh Piatnitsky, you cannot be with them, my heart refuses to accept it.

If it must be, if they haven't withdrawn their accusations against you, then I will adopt the official view in all of my dealings with you and will never be near you, but I cannot think of you as a liar before the Party or a counterrevolutionary. But if it turns out to be true, can I remain among free Soviet citizens? And die? At a time when the dark forces are rising against us, when the last and perhaps decisive battle is coming, and soviets are being formed in other countries? And leave my children behind? I feel like I can't sleep, don't want to see anyone, don't want to move. It frightens me to be wearing Piatnitsky's slippers (flat ones with no heels), and I feel really sick to my stomach after my dance. This was the first time my body has been inspired by anything since Piatnitsky's arrest." 21

Yulia and Vova followed the trial in the newspapers. Vova read the transcripts every day after school. He asked his mother how the murderers had prepared poison and told her that he thought Koltsov's description of Krestinsky's attempt to retract his testimony was very funny. ("In a brilliant display of cross-questioning, the public prosecutor Comrade Vyshinsky corners the mangy Trotskyite rat. Its squeaking is growing more confused.") They spent their evenings reading Jules Verne's The Mysterious Island aloud. On March 13, the sentences were announced. ${ }^{22}$

"Today at 4 p.m. they will be liquidatedthese terrible villains of our land. They managed to weave such a vast and intricate web that even those who hate them as much as Comrade Ezhov hates them and as much as every honest and conscientious citizen of our country hates them have been caught up in it. In addition to the colossal material damage, they have inflicted moral wounds on us. So much remains to be untangled, pondered, destroyed, cured, and neutralized in time, and among them there is, of course, some of the 'living flesh' of Lenin's and Stalin's Party, whose suffering has been immeasurable, even though I have only a dim understanding of it. Who will pay for it? Who will give back the lost months of my life, the possibility of working shoulder to shoulder with my comrades at such a time? Who will make up for this unmarried loneliness? Their disgraceful, vile blood is too small a price for all the grief felt by the Party and by all those who have some feeling left, for the suffering of those innocent people who have been removed from society, people who have given everything for the revolution, every drop of their strength, not realizing that there existed such two-legged monsters, such cretins who were so good at dissembling. I do not know of a more terrible creature than Bukharin, it is hard for me to express what I feel. Now they will be destroyed, but my hatred will not be diminished. I would like a terrible punishment for them - we could put them in cages built especially for them in a museum, 
labeled 'counterrevolutionaries', and take care of them as if they were rare specimens. That would be terrible for them: citizens would come and look at them the way you look at animals. Hatred for them would never die, and they would be forced to see how we fight for a happy life, how united we are in our struggle, how much we love those of our leaders who remain true, how we triumph over fascism while they sit around idle, being fed like animals and not being considered human. [...] I curse you all, curse you for eternity." 23

On March 9, she went to see the chief military prosecutor, Naum Rozovsky. She was nervous and, according to her diary, "spoke unintelligently and said all the wrong things." So did the prosecutor.

"Comrade Rozovsky is also exhausted, he screamed at me angrily, with great emotion. I even felt sorry for him, for I only subsist while he works, and such a hard job it is, too. Oh, how dear they are to me, how I wish they could trust me! I would happily give my life for something useful, but coming from me it must sound untrue... I know that the best thing for me is death. But then again, it's probably wrong for me to kill myself. What did I feel in Rozovsky's office? One should always rise above one's private interests - always, but especially in my state, when I have and will have nothing, so I must find work I can live for." ${ }^{24}$

Such work could be found. She needed the NKVD in order to find out what had happened to her husband and son; she admired the NKVD for the difficult work they were doing; and she needed the NKVD's trust in order to resolve her doubts. Working for the NKVD might be the best, and perhaps the only, way to become whole again. On April, 14, she went to see Rozovsky again.
"I spoke of my intention of putting myself at the disposal of the NKVD and military organs. He told me that I should express this wish in writing and not be shy about being long-winded, so that I could make myself completely clear. He did not promise anything concrete, but he did promise to try to help me. The letter must be handed to Medvedev. He must have been as humane with me as his position allowed. I could tell that he was exhausted and that he truly cared. I shook his hand firmly, although perhaps that was excessive sentimentality, which I keep trying to overcome, but when I saw in him a person who was doing a job that was difficult yet so necessary at this time, I wanted to express my admiration for those comrades, my heartfelt kinship with those who are uprooting all kinds of scum from our Party." 25

It did not work. Next time she saw Rozovsky, he was cold and indifferent. She began to doubt the one thing that had seemed solid.

"The most frightening thing within me is the growing distrust for the quality of people who conduct investigations and have the right to arrest. Of course, I realize that Ezhov and some others, both top-level and low-level officials, are wonderful, genuine people who are doing extraordinarily difficult work, but the majority - they are also doing difficult work, but as stupid and petty people capable of meanness. It's a shame I feel this way, but the facts (the things I have experienced myself, things I have seen, as single strokes here and there, things I happen to have heard from other people standing in prison lines) make it impossible to feel differently." 26

She tried to talk to different people, but they would not listen. Some laughed at her. She used to have Piatnitsky to talk to, but he was not there anymore and might 
or might not be the reason for the silence that surrounded her. The last entry in her diary, under May 28, 1938, is:

"I used to talk his ear off, but I never needed anyone else to talk to, and I still won't, except perhaps to someone from the NKVD. In spite of everything, I feel closer to them." ${ }^{27}$

Several weeks later she got a job as an engineer at a hydroelectric power plant in Kandalaksha, on the White Sea. She took Vova with her. On October 27, 1938, she was arrested for telling an NKVD informer that her husband was innocent. Her diary was used as evidence against her. She was sentenced to five years in a labor camp and sent to the Dolinsky Camp in Kazakhstan, where she saw Igor. Vova ran away to Moscow and was taken in by the family of his friend, Zhenia Loginov, from Apartment No. 89. After three months of living with the Loginovs, Vova overheard one of them say that his stay was causing Zhenia's father problems at work, so he went to the Executive Committee of the Moscow City Council and was sent to an orphanage. ${ }^{28}$

\section{$* * *$}

According to the grown-up Vladimir Piatnitsky, Zhenia Loginov's father worked in Stalin's secretariat. The Loginovs' act taking in the enemy's progeny - was uncommon, but not unheard of. But most "family members of traitors to the motherland" (as they were described in Order No. 00486) were helped by other family members. And most families' central figure - not targeted by the mass operations and not questioning the duty to help - was the grandmother. Svetlana Osinskaia's maternal grandmother, Ekaterina Nartsissovna Smirnova, was not unusual.
"She was quiet, but firm and unflappable. Short, with soft grey hair cozily pinned back with horn hairpins, she wore long, dark skirts and buttoned-up blouses with a tie or bow at the collar and a small brooch with tiny pearls. Several letters from my grandmother to my mother that I have kept suggest that she was a person of great integrity. Her letters are plain: she talks unaffectedly about her health and simple chores, but her dignity comes through clearly. Those traits of hers bordered on coldness. She was never openly affectionate with us or particularly curious, and never singled anyone out. With the calm of a self-confident and deliberate person, she made jams at the dacha, provoking my great admiration for her ability to remove cherry pits by means of a hairpin, mended clothes, and made wonderful toys for New Year's: a tiny little chest with blue silk lining, a small leather bag stuffed with candy, and little dolls in bright dresses. Spared miraculously by life's upheavals, they stayed with me for a very long time. When my parents were arrested, she did not become frightened, but came over the morning after my father's arrest and stayed with my mother until she was arrested. After that, she came over almost every day and did her best, along with several other people, so that we could go on with our normal lives." ${ }^{29}$

She did eventually take Svetlana (who was twelve), Rem (fourteen), and Valia (fifteen) to an orphanage - she lived with her niece in a twelve-meter room in a communal apartment, - but she remained the center of the truncated family and regularly sent news, food, and money to her daughter and grandchildren. The same was true of Arkady Rozengolts's mother-inlaw, who took care of her grandchildren until the war made it impossible. Many children, including Inna, Natalia, and Valentina Gaister, Yuri and Tania Trifonov, 
and Rada Poloz (Tania Miagkova's daughter), were raised by their grandmothers all of whom were described as dry, unsentimental, and unquestioningly devoted. The fact that two of the three - Tatiana Aleksandrovna Slovatinskaia and Feoktista Yakovlevna Miagkova - were orthodox Bolshevik sectarians does not seem to have diminished their family loyalty. The fact that their families were punished for unexplained reasons does not seem to have diminished their Bolshevik orthodoxy. The two sets of loyalties - shared by their children, instilled in their grandchildren, and maintained painstakingly to the end of their lives - were connected to each other by silence.

Uncles and aunts - the brothers and sisters of arrested enemies - had a more difficult choice to make. They were vulnerable to arrest and had reason to believe that associating with a contaminated relative might increase the risk. Some had children of their own, to whom they owed primary loyalty. Some were members of the Party, to which they owed primary loyalty (and from which they expected extra scrutiny and harsher punishments). Some were both parents and Party members.

The children of the People's Commissar of the Food Industry, Abram Gilinsky, twelve-year-old Nelly and two-year-old Tania, were sent to an orphanage, but Nelly refused to cooperate ("breaking windows, rolling on the floor"), until the principal informed her aunt (her mother's sister, Lydia Mefodievna Stechkina). When the aunt arrived, she asked the principal what would happen to her and her husband, both Party members, if they adopted the two girls. The principal said (accurately, according to Order No. 00486) that there would be no negative consequences, and the aunt took them back with her. The six of them - Nelly and Tania, their aunt and uncle, and their aunt's grown-up adopted daughter and her husband - shared two rooms in a communal apartment. Nelly and Tania were to call their aunt and uncle "mom" and "dad". A month later, the uncle, Vasily Stepanovich Kraiushkin, was arrested. The aunt went on to become the girls' adoptive mother. (Their mother died in exile in 1949.) Their half-brother, the nineteen-year-old David (Gilinsky's son from a previous marriage) became "like a father" to them. Gilinsky's three brothers, who lived in Leningrad, helped out the best they could. ${ }^{30}$

When the Deputy Commissar of the Defense Industry, Romuald Muklevich, returned home to Apartment No. 334 after the arrest of his wife, Anna (Head of Supplies at the State Planning Committee), he was visited by his brother-in-law and old Civil War comrade, the director of the Aviation House, Matvei Yakovlevich Sheiniuk. Muklevich's daughter, Irina, heard her uncle say that, if Muklevich was arrested, he would take Irina to live with him and take care of her as long as he lived. After Muklevich's arrest, he did take her to live with him. Several months later, he, too, was arrested, and Irina was raised by her aunt and grandmother. ${ }^{31}$

Was Sheiniuk arrested because of his loyalty to the Muklevichs? No one knew for sure, but it made sense to assume a connection. When the People's Commissar of State Farms, N. N. Demchenko, and his wife, Mirra Abramovna, were arrested, their eldest son, nineteen-year-old Kolia, talked his uncle into sheltering his eleven-year-old brother Feliks (named after the founder of the Cheka). When he next came to visit, his uncle opened the door without undoing the chain and told him through the crack that, in order to sever all links with the enemies of the people, he had taken Feliks to an orphanage. At the orphanage, Kolia was told that he was not in a position to adopt his brother. In order to qualify, Kolia 
married his girlfriend, Tatiana, thereby provoking the "desperate envy" of his roommate, Samuil Moroz. A week later, both Kolia and Samuil were arrested. ${ }^{32}$

Inna Gaister's Uncle Veniamin (a researcher at the Institute of World Economy and International Politics), attempted to cut off all contact with his arrested relatives, but was seemingly left with no choice but to take in his mother, who was visiting from Poland, after three of his sisters (Lipa, Adassa, and Inna's mother, Rakhil) were arrested. Their twentyyear-old brother Lyova was a student at the Bauman Institute at the time. As Inna writes in her memoirs,

"After my mother and Lipa were arrested, Grandma Gita went to live with Adassa. After Adassa was taken to prison, her son Veniamin took her in. Sometime in early December, Elochka, Aunt Lipa's daughter, came home from school one day to find Grandma Gita sitting on the stairs in front of their apartment. Veniamin, without warning Niuma (Lipa's husband) or Lyova, had brought her there and left her by the locked door. Grandma moved in with them. I would often see her there. She was no longer the same proud and happy Grandma I had seen arrive from Poland. I can still picture her with her red wig all twisted round and her bun hanging over her ear. She could not understand why her children had been imprisoned. She kept pacing up and down the apartment, intoning: "It's all my fault. I have brought grief to my children. I must return home immediately. As soon as I leave, things will get better again." She was saying all this in Yiddish. Of course, Elochka and I did not understand a word of Yiddish, so Lyova had to translate for us." ${ }^{33}$

Inna's mother, Rakhil Kaplan, had been sent to the Akmolinsk Camp for Family Members of Traitors to the Motherland in
Kazakhstan. One of her letters contained a note to Veniamin, in which she asked him to take care of her children.

\begin{abstract}
"After what had happened with Grandma Gita, I did not want to go to Veniamin. But Niuma and Lyova talked me into taking the note to him, and so Lyova and I went over to his place. He and Sarra were home. They took my mother's note and went into his study. Then Sarra came out and said: 'Go away and never come back'. Veniamin did not come out. Lyova and I left without saying a word. That did not save Veniamin from prison, however." 34
\end{abstract}

Dima Osinsky's wife, Dina, was being exiled to Kharkov, which meant that his younger siblings Svetlana and Valia and their adopted brother Rem Smirnov would have no place to live and be taken to an orphanage. According to Svetlana,

"The matter resolved itself, somehow. We would go to the orphanage, but not for long because, of course, everything would soon be cleared up. But, just in case, Dina sent us over to my father's sister, Galina, who was also my mother's closest friend, to ask for advice. She lived with her husband, the chemist, S. S. Medvedev, the future famous scholar and full member of the Academy of Sciences, and their son, who was a little younger than me. I had been to their place - three small rooms in a communal apartment in a tall building with a dark stairway on the corner of Krivokolenny and Armiansky Alleys - many times before with my mother. The walls of Galina's room were covered with pictures, including a large portrait of her: a handsome, thin, perfectly proportionate face, dark wavy hair, and a blue blouse with a wide-open white collar. Next to it were some of her own drawings. Aunt Galia was an artist and worked at the Vakhtangov Theater. 
That spring day in 1938, Valia and I went to Aunt Galia to ask advice about our future, which had, in fact, already been decided. We climbed up the tall staircase and rang the doorbell. Aunt Galia opened the door. My God how scared she was! She didn't know what to do. We stood in our coats in the large dark entryway, while she disappeared somewhere into the bowels of her rooms. Soon she came back and started stuffing our pockets with candy. 'You can't stay here,' she said quickly and softly, 'Sergey Sergeevich is working. He mustn't be disturbed.' She kept pushing us gently toward the door. When we had all walked out onto the stairway, she seemed relieved. 'Don't ever come back again, okay? Now go.' So we left and walked home in silence. When he got home, Valia, who had never cried once during those six months, buried his face in his pillow and sobbed." ${ }^{35}$

Close friends were in a similar position - and were frequently referred to as "uncles" and "aunts". One of Irina Muklevich's real aunts, her mother's sister Maria, had a friend named Anton Ionych Shpektorov, an official at the People's Commissariat of External Trade (headed, after Rozengolts's arrest, by A. I. Mikoian). He had "a personal car with a chauffeur, two secretaries, and the use of the government cafeteria, exclusive sanatoria, etc., etc.", but he "was not afraid of anything and came to see us almost every day." (He may have been in love with Irina's aunt, but the risk remained the same, whatever the reason for such open loyalty). Other friends, according to Irina, acted differently. ${ }^{36}$

"Three days after my father's arrest, my aunts Nina and Meli (my father's sisters) walked into the entryway and saw my parents' close friend, the Old Bolshevik, Mikhalina Novitskaia [Michalina
Nowicka], who had worked for many years at TASS, as Doletsky's personal secretary. They were all waiting for the elevator. When she saw my aunts, Mikhalina did not say hello and did not enter the elevator. She simply stepped aside and turned away. My aunts were shocked. It was as if she had spat in their faces.

Of course, Mikhalina did not know then that a month later her own husband, an old Bolshevik and top official of the Comintern Executive Committee [Waclaw Bogucki], would be arrested; she would be sent to a camp for eight years; and her son [Vladimir] would be taken to an orphanage. And that after her return she would spend many years looking for her son and that she would never find him because he had been sent to prison for ten years for stealing a watermelon and a cantaloupe from the field when he was hungry. And that she would come to me when she had no place to go in Moscow, and I would take her in. All that happened. She would end her days in a retirement home, lonely and sick." 37

In memoirs and reminiscences, such actions are featured prominently and represented as acts of betrayal, often followed by providential retribution. Most House of Government residents - including those like Piatnitskaia, who thought of themselves as Bolsheviks and were not convinced of their relatives' (or even their own) innocence before the Party seem to have expected loyalty from their friends, lovers, and relatives, irrespective of whether they were Party members or not. Some self-sacrificial actions and individuals might be singled out for admiration, but most such actions and individuals were mentioned without comment, as part of the normal course of things. Friends, lovers, and relatives were, then and later, 
depicted as having been subjected to a test of humanity. Some passed, proving themselves to be "true" (in the sense of both "loyal" and "genuine"), and some did not. And since friends, lovers, and relatives were expected to be true, by definition, those who did the right thing might or might not, depending on the other factors involved, be seen as heroic. Those who did not were consistently singled out - and often deliberately exposed - as traitors and "bad people". There were countless shades of grey, forgiven trespasses, and attenuating circumstances in between, but the endpoints on the scale of goodness were clear enough. "Good people" were those who were prepared to risk their own safety and that of their immediate family for the sake of friends, lovers, and other relatives. "Bad people" were those who wished to protect themselves and their immediate family to the exclusion of all other loyalties and commitments. The orthodox Bolsheviks who turned away their nephews and nieces because the only true family was the Party were acting like bad people. In accounts written in the post-sectarian world, these orthodox Bolsheviks and bad people became indistinguishable. Feliks Demchenko's and Inna Gaister's uncles were bad people - both at the time and in the retelling - irrespective of whether their reasons were self-servingly egotistical or self-denyingly sectarian.

Family morality within the House of Government, like the sectarian morality of Party purges, was centered on trust and betrayal. But whereas the purge morality was concerned with secret thoughts as opposed to actions (or rather, with hypothetical actions as emanations of deviant thoughts), family morality was focused on actions as proof of moral choices. Lydia Mefodievna Stechkina, Matvei Yakovlevich Sheiniuk, and Anton Ionych Shpektorov were good people irrespective of whatever private fears they may have had to overcome. Indeed, they were all the more remarkably good people for having overcome their private fears and silently reconciled their sectarian commitments with those toward kith and kin (all three were Party members). The Party itself could not quite make up its mind: it exiled entire clans and punished "family members of traitors to the motherland," while proclaiming, from Stalin's mouth, that "sons do not answer for their fathers" and encouraging, inconsistently but forcefully, the reintegration of those sons into the Soviet family. In a note to her from prison, Irina Muklevich's mother wrote: "Whatever happens to us, always remain a true Soviet." And that is how Irina's aunt, a good person and a true Soviet, brought her up. The key to being a good Soviet while having a mother in prison was silence. ${ }^{38}$

The more intimate the relationship and the thicker the web of mutual obligations, the greater the expectation of loyalty and the more painful the betrayal (very rare in the case of parents and children). The more distant the relationship and less anticipated the favor, the greater the virtue. The Loginovs took in an enemy's son because he was their own son's friend. Irina Muklevich had a school friend, Shura Elchugina, who lived in the dormitory for Military Academy cadets across the river. (Her father was a maintenance worker at the Academy.) After the arrest of Irina's parents, the Elchugins invited her to stay at their place, and Shura's mother made her a dress. Vasily Shuniakov, a former Petrograd worker and Central Control Commission official specializing in purges and his wife, Iudif Charnaia, a former seamstress and education official specializing in pedology (until it was banned by Volin and Rabichev), let their daughter's friend, Katia Dushechkina (from Apartment No. 422), stay with them for a while after 
her parents were arrested. According to their daughter, Tamara, they were visibly frightened by what was happening and burned many of their books; Vasily started drinking. ${ }^{39}$

The former chairman of the Flour Milling Industry Directorate, Boris Ivanov, his wife, Elena Yakovlevna Zlatkina, and their three children (Volodia, Anatoly, and Galina) occupied two rooms of their threeroom apartment and rented out the third. Their first tenant, Professor Lebedev, was arrested very early, perhaps as early as 1935. Their next tenants were a MarxismLeninism instructor named Krastinšs, and his wife and daughter. Once, in the middle of the night, the doorbell rang. Anatoly, who was seventeen at the time, opened the door, saw several NKVD agents, walked over to where his father was sitting at his desk (he used to work late), and said: "Get up, Dad, it turns out you're a bastard. They've come for you." The agents came in, asked everyone for their names, and moved on to the room where the Krastinš lived. A few days later, that room was occupied by the wife and two daughters of the recently arrested head of the CattlePurchasing Trust, N. A. Bazovsky, from Apartment No. 377 three floors above. Shortly afterwards, Bazovsky's wife was also arrested. Her daughters were not home at the time, and Elena Yakovlevna told Anatoly and Galina (who was fifteen) to save as many of the Bazovskys' belongings as they could. She also told Galina to stand watch downstairs and warn the Bazovskys' older daughter, Nina, not to come up. (The younger one, Olga, was out of town, visiting her aunt.) The guard on duty, named Niura, told Galina to go back to her apartment and promised to call her when Nina showed up. (According to Galina, the guards liked her family and treated them well.) She did; Galina warned Nina; and Nina went to live with her relatives. Meanwhile, the husband of Elena Yakovlevna's sister, an aviation engineer, had been arrested, and the sister had moved in with the Ivanovs. One day, on the Big Stone Bridge, she ran into the fifteen-year-old Olga Bazovskaia, who told her that her aunt had thrown her out and that she had no place to stay. Elena's sister invited her over, and she ended up moving in with them. Boris Ivanov (who had known the Bazovskys as apartment neighbors for about three months) registered her in one of his two rooms. (The third room was now occupied by the Commissariat of Finance official, V. M. Buzarev, and his family.) Galina and Olga became close friends and treated each other like sisters. According to Galina, her parents remained orthodox Bolsheviks. Her father had recently become secretary of the Party organization and head of the personnel department at the People's Commissariat of Food Industry; her mother was a member of the Moscow City Soviet. They never talked about their arrested relatives and neighbors, including Olga's parents. When Krastiņš returned from prison a year or so later, he stayed with them for several days. According to Galina, he had no teeth and was dressed in rags; he went straight to the bathroom, saw the soap, and started crying. Olga lived with the Ivanovs for about ten years; they raised her as a daughter. When Olga's mother came back from the camps, she also stayed with them for a while. According to Galina, she once said: "If I had been in Elena Yakovlevna's place, would I have done what she did? Would I have taken Galka in? No." The world was divided into good people and bad people. Everyone - Party and non-Party seemed to agree that Boris Ivanov, the baker, and his wife, Elena Yakovlevna Zlatkina, were very good people. ${ }^{40}$ 
The Elchugins', Shuniakovs', and Ivanovs' actions may have had something to do with the fact that they were former workers and peasants, not "students", and that they assumed that being a good Soviet was compatible with fulfilling traditional neighborly and kinship obligations (just as it was compatible with not celebrating New Year's Eve and grownups' birthdays). Perhaps they found it easier to use silence as a bridge between faith and social practice. The House of Government's most articulate intellectuals and prominent experts on Bolshevik morality - the author of Soviet family law, Yakov Brandenburgsky, and his coauthor and chess partner, "the Party's Conscience" Aron Solts, - were not up to this task. In late 1936, Brandenburgsky, who was then chair of the Collegium for Civil Cases of the Soviet Supreme Court, began to act strange, telling his family that he was afraid to go to work. In December, his wife and twenty-three-year-old daughter, Elsa, received a call from the mental hospital ("Kanatchikov's Dacha") that he had been picked up on the street in a state of complete disorientation. After some time, they were allowed to bring him home, but he refused to eat and was taken to the Pirogov Hospital. "When we came to visit," said his daughter in an interview sixty years later,

"We found a complete stranger, suffering from fatigue. A sybarite by nature, he seemed totally unaffected by the company of madmen, screaming, squealing, and crawling on the floor beside him. The room was filled with very sick people, but my father seemed perfectly comfortable there. He had even found a friend - a dwarf with a contorted face, - whose company he seemed to enjoy. [...] He would sometimes say things that made no sense to us. Once he became agitated: 'Why did you write my name on the box of chocolates? They might find me that way!'41

In late 1938, after the mass operations were over, Brandenburgsky suddenly recovered and returned home. He retired from the Supreme Court and became a volunteer lecturer at the Moscow Party Committee. He died in 1951 at the age of seventy, while playing chess. He never talked about his illness. ${ }^{42}$

Solts served as First Deputy Prosecutor General for Criminal Cases and lived with his adopted son, Evgeny, and his niece, Anna Grigorievna Zelenskaia. His sister, Esfir, had died in 1935. After the arrest of Anna's former husband, Isaak Zelensky, their two children, eighteen-year-old Elena and sixteen-years-old Andrei, joined their mother in Solts's apartment, and he adopted them, too. On February 14, 1938, he had a violent argument with his boss, the Prosecutor General A. Ya. Vyshinsky, about the case of his friend and disciple, Valentin Trifonov, who had been arrested on June 21, 1937. According to Elena, he came home very upset and said that Vyshinsky had threatened him, too. He decided to stop eating in the hope that Stalin would agree to talk to him. Several days later, he was taken to the ward for the violently insane at the Sokolniki PsychoNeurological Hospital. According to his doctor, who knew him from her previous work as consultant for the Amnesty Board, which Solts chaired, he blamed the demise of the Old Bolsheviks on the rise of opportunists. "'Who is Ezhov? Why should I believe Ezhov? The Party does not know Ezhov!', Solts would say. 'Vyshinsky, a former Menshevik, is going to interrogate me? A Menshevik is going to sit in judgment over Bolsheviks?!" He abandoned his hunger strike and, a month and a half later, 
was allowed to return home in exchange for a guarantee from his niece Anna that he would not pose any danger to himself or others. Two and a half months later Anna was arrested. Solts wrote a letter to his former colleague, the chairman of the Military Collegium of the Supreme Court, Vasily Ulrikh, but received no response. He was removed from his position and then worked as a literary consultant for the Young Guard Publishers and director of the archive of the Museum of the Peoples of the USSR, before retiring in 1940 at the age of sixtyeight. "He suffered terribly from the enforced idleness," wrote Elena. "He spent hours lying in bed reading or pacing around the apartment writing long columns of numbers on pieces of paper or in newspaper margins." 43

\section{ATSAUCES UN SKAIDROJUMI}

${ }^{1}$ I. R. MukLEvich. Dear friend [in Russian]. Arhiv muzea "Doma na naberežnoi" [House on the Embankment Museum archive], Moscow (hereafter - AMDNN), file 28.

${ }^{2}$ Mikhail Tomsky (1880-1936) committed suicide in 22 August, 1936 (editor).

${ }^{3}$ Olga Aroseva. Prozhivshaia dvazhdy, 24 August, 1936. Available: http://lib.rus.ec/b/387149/ read

${ }^{4}$ LION FeJHTVAnger. Pervye vpechatlenija ob jetom processe. Pravda, 30 January, 1937.

${ }^{5}$ Ibidem.

${ }^{6}$ V. B. Volina interview, 18 September, 1997; V. D. Svarts interview, 10 September, 1998. "Black raven" was a colloquial term for "prison van".

${ }^{7}$ VASILII SoIMA. Zapreshchennyi Stalin. Moskva 2005, pp. 97-98.

${ }^{8}$ Rossijskij gosudarstvennyj arhiv literatury i iskusstv, Moscow, 457-391, pp. 199-199 ob.

${ }^{9}$ Gosudarstvennyj arhiv Rossijskoj Federacii, Moscow, 5446-82-65, pp. 182-184.

${ }^{10}$ Rossijskij gosudarstvennyj arhiv social'no-politicheskoj istorii, Moscow (hereafter - RGASPI), 135-2-19, p. 57.

${ }^{11}$ Ibidem, pp. 56-56 ob.

${ }^{12}$ Ibidem, 74-2-105, pp. 41-2, 47, 51, 55, 59-60 (cited in: BoRIs SoKOLOv. Dva marshala: Tragicheskii roman v pis'makh. Grani.ru, 21.02.2003. Available: http://grani.ru/Society/ History/m.23664.html); Rossijskij gosudarstvennyj voennyj arhiv, Moscow (hereafter - RGVA), 37461-1-134, p. 25.

${ }^{13}$ RGVA, 37461-1-134, pp. 15-15 ob.

${ }^{14}$ Ibidem, 37461-25-128, pp. 7-9.

${ }^{15}$ AMDNN, Ankety. Otvety M. I. Dement'evoi (Agroskinoi); AMDNN, Ruslan Nikolaevich Gel'man, Letter to the Museum.

${ }^{16}$ VlAdimir PiAtnitskiI. Golgofa. Po materialam arkhivno-sledstvennogo dela No. 603 na Sokolovu - Piatnitskuiu Iu. I. Leningrad 1993, p. 46.

${ }^{17}$ Ibidem, pp. 41-42.

${ }^{18}$ Ibidem, pp. 56, 46.

${ }^{19}$ Ibidem, pp. 63-64.

${ }^{20}$ Ibidem, p. 61.

${ }^{21}$ Ibidem, pp. 51-53.

${ }^{22}$ Ibidem, p. 57; Mikhail Kol'Tsov. Svora krovavykh sobak. In: Pravda, 03 March, 1938.

${ }^{23}$ PIATNITSKII, Golgofa, pp. 57, 60-61. 
${ }^{24}$ PIATNITSKII, Golgofa, p. 79.

${ }^{25}$ Ibidem, pp. 82-83.

${ }^{26}$ Ibidem, p. 103.

${ }^{27}$ Ibidem.

${ }^{28}$ Ibidem, pp. 13-16, 104-120; INNA SHIKHEEVA-GAISTER. Deti vragov naroda: Semeinaia khronika vremen kul'ta lichnosti 1925-1953. Moscow 2012, pp. 55-57.

${ }^{29}$ Svetlana OBolensKAiA. Iz vospominanii. Available: http://samlib.ru/o/obolenskaja_s_w/01. shtml

${ }^{30}$ N. A. Gilinskaia interview, 02 March, 1998.

${ }^{31}$ Muklevich, Dear friend. AMDNN, 12; I. R. Muklevich interview, 07 November, 1997.

32 Nikolaj N. DemchenKo. Kanikuly dlinoi v 18 let. In: Mendeleevets 36, 1988, No. 1799.

${ }^{33}$ SHIKHEEVA-GAISTER, Deti vragov naroda, pp. 57-58.

${ }^{34}$ Ibidem, p. 66.

35 Obolenskaia, Iz vospominanii; SvetLana OBolEnsKaIA. Deti Bol'shogo terrora: Vospominaniia. Moscow 2013, pp. 55-56.

${ }^{36}$ MuKLEvich, Dear friend. AMDNN, pp. 62-63.

37 Ibidem, pp. 24-25; Vladimir V. BOGUTSKII. Vospominaniia. C AOM. Archive of the Memorial Society, fond 2 (memoir collection), pp. 7-8.

${ }^{38}$ See Golfo Alexopoulos. Stalin and the Politics of Kinship: Practices of Collective Punishment, 1920s-1940s. In: Comparative Studies in Society and History 2008, No. 1, pp. 91-117; CYNTHIA HOOPER. Terror of Intimacy: Family Politics in the 1930s Soviet Union. In: CHRISTINA KIAER, ERIC NAIMAN (eds.). Everyday Life in Early Soviet Russia: Taking the Revolution Inside. Bloomington 2006; AMIR WEINER. Nature, Nurture, and Memory in a Socialist Utopia: Delineating the Socio-Ethnic Body in the Age of Socialism. In: American Historical Review 104, 1999, No. 4, pp. 1114-1155.

${ }^{39}$ MukLEVICH, Dear friend. AMDNN, pp. 30-1; I. R. Muklevich interview, 07 November, 1997; T. V. Shuniakova (Ignatashvili) interview, 22 April, 1998.

${ }^{40}$ G. B. Ivanova interview, 13 March, 1998.

${ }^{41}$ IUdit AgracheVA. Chlen partii s 1903 goda. Vesti-2, 01 June, 1995.

${ }^{42}$ Ibidem; "Biografiia" and "Avtobiografiia". AMDNN, the Brandenburgsky file, KP 371/17, KP 3771/18.

${ }^{43}$ E. I. ZelensKaiA. A. A. Sol'ts. Unpublished manuscript. AMDNN, "Solts" file, pp. 68-92; C. YURY TRIFONOV. Disappearance. Translated by David Lowe. Ann Arbor 1991, pp. 99-100; C. YURY TRIFONOV. Ischeznovenie. Available: http://royallib.ru/read/trifonov_yuriy/ischeznovenie. html\#0

\section{SUMMARY}

This is an abridged and slightly revised version of a chapter from my book The House of Government: A Saga of the Russian Revolution (Princeton University Press, 2017). The House of Government - also known, after Yuri Trifonov's novella, as the House on the Embankment - was built in central Moscow during the first Five-Year Plan in order to serve as a home for the members of the Soviet government. The largest residential building in Europe, it combined 505 fully furnished family apartments with public spaces including a cafeteria, theater, movie theater, grocery store, walk-in clinic, child-care center, hairdresser's salon, post office, telegraph, bank, gym, laundry, library, tennis court, 
and several dozen rooms for various activities (from pool-playing and target shooting to painting and orchestra rehearsals).

In the 1930s and 40s, about 800 House residents and an unspecified number of employees were evicted from their apartments and accused of various crimes. 344 residents are known to have been shot; the rest were sentenced to various forms of imprisonment.

This chapter deals with the residents' reactions to mass arrests and the puzzle of what kind of behavior was morally appropriate. Who was, under those circumstances, a "good person"?

\section{KOPSAVILKUMS}

Šis raksts ir autora grāmatas "Valdības nams: Krievijas revolūcijas sāga" saīsināta un nedaudz pārveidota versija, grāmata iznāca Prinstonas Universitātes apgādā 2017. gadā (Princeton University Press, 2017). Valdības nams, kas pēc Jurija Trifonova romāna ir plaši pazīstams arī kā Krastmalas nams, tika uzbūvēts Maskavas centrā pirmās piecgades laikā, to bija paredzēts izmantot kā padomju valdības locekḷu apartamentu kompleksu. Tas bija lielākais dzīvokḷu komplekss Eiropā ar 505 pilnībā apgādātiem apartamentiem un koplietošanas telpām - kafejnīcu, teātri, veikaliem, klīniku, bērnudārzu, frizētavu, pasta nodaḷu, telegrāfu, bankas nodaḷu, sporta zāli, veḷas mazgātavu, bibliotēku, tenisa kortu un vairākiem desmitiem telpu dažādām aktivitātēm, sākot no biljarda zālēm un telpām mērḳi šaušanai līdz gleznošanai un orḳestra mēǵinājumiem.

Pagājušā gadsimta 30. un 40. gados apmēram 800 nama iemītnieku un nenoskaidrots skaits darbinieku tika izraidīti no vinu apartamentiem un apsūdzēti dažādos noziegumos. 344 iemītnieki, cik zināms, tika sodīti ar nāvi nošaujot, pārējiem tika piespriests dažāda veida un ilguma ieslodzijums.

Šajā rakstā aplūkota nama iemītnieku reakcija uz masu arestiem un sarežgītais jautājums par to, kādi uzvedības veidi bija morāli pien,emami. Kurš šajos ekstraordinārajos apstākḷos varēja sevi saukt par labu cilvēku? 